\title{
THE CDKN2A (p16) GENE AND HUMAN CANCER
}

\author{
William D. Foulkes,* Tamar Y. Flanders,* Pamela M. Pollock, ${ }^{\dagger}$ \\ and Nicholas K. Hayward ${ }^{\dagger}$ \\ *Division of Medical Genetics, Department of Medicine, McGill \\ University, Montreal General Hospital, Montreal, Canada \\ ${ }^{\dagger}$ Queensland Cancer Fund Research Unit, Queensland Institute of \\ Medical Research, Queensland, Australia
}

\section{SUMMARY}

$C D K N 2 A$, the gene encoding the cell-cycle inhibitor p $16^{C D K N 2 A}$, was first identified in 1994. Since then, somatic mutations have been observed in many cancers and germline alterations have been found in kindreds with familial atypical multiple mole/melanoma
(FAMMM), also known as atypical mole syndrome. In this review we tabulate the known mutations in this gene and discuss specific aspects, particularly with respect to germline mutations and cancer predisposition.

\section{INTRODUCTION}

\section{CDKN2A-the Gene}

$C D K N 2 A$ has been given different names $\left(\mathrm{p} 16^{I N K 4}, \mathrm{pl} 6^{I N K 4 A}, C D K 4 I, M T S 1\right.$, and $\left.p 16\right)$ by different investigators, but was recently assigned the designation CDKN2A (for cyclin dependent kinase inhibitor $2 A$ ) by the Human Genome Organisation nomenclature committee. The gene is composed of 3 exons, with one alternatively spliced exon $(\mathrm{El}-\beta)$. It is situated on chromosome $9 \mathrm{p} 21$, in a region that shows a high frequency of loss of heterozygosity $(\mathrm{LOH})$ in numerous tumor types (1). The gene itself is mutated (or inactivated in some way) in many types of human cancers. In this sense, CDKN2A bears a striking resemblance to the paradigmatic tumor suppressor gene, $p 53$. CDKN2A may prove to be as important a regulator of cell growth as $p 53$.

Address correspondence and reprint requests to: William D Foulkes, Division of Medical Genetics, Department of Medicine, McGill University, Montreal General Hospital, 1650 Cedar Ave., Montreal, Quebec, Canada H3G IA4.
An interesting parallel between these two genes can be drawn upon examination of the tumor spectrum observed in families carrying germline mutations. Although both genes are somatically altered in a wide variety of cancers, there is a more specific pattern of malignancy associated with germline mutations. For instance, CDKN2A somatic mutations (mainly deletions) are common in glioblastoma (2), but a case of glioblastoma has not yet been reported in a familial atypical multiple mole/melanoma (FAMMM) kindred, where cutaneous malignant melanoma is by far the commonest cancer (3). Similarly, colorectal and ovarian cancer frequently exhibit somatic $p 53$ mutations (4). However, these cancers are rarely seen as part of the familial Li-Fraumeni syndrome, which typically features soft tissue sarcomas, leukemia, and brain cancers in children, and breast cancer in young women (5).

\section{p16 $^{\text {CDKN2A }}$ - the Protein}

CDKN2A encodes a 156 amino acid, $16 \mathrm{kD}$ cellcycle inhibitor protein, which normally blocks 


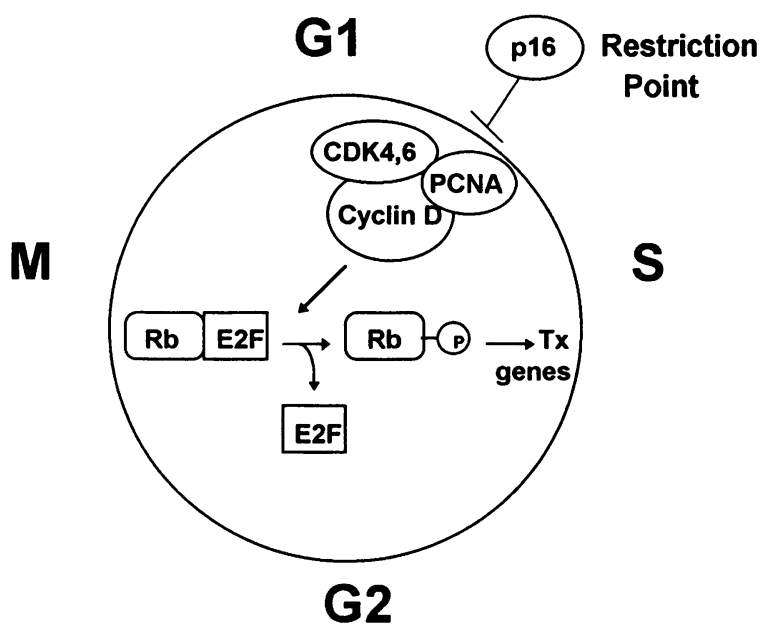

FIG. 1. Diagrammatic representation of the involvement of (p16) in cell cycle regulation Abbreviations are as follows: CDK, cyclin-dependent kinase; PCNA, proliferating cell nuclear antigen; $\mathrm{Rb}$, retinoblastoma gene product; $E 2 F$, transcription factor; $\mathrm{P}$, phosphate; Tx genes, gene transcription; pl6, $C D K N 2 A$ gene product.

abnormal cell growth and proliferation by binding to complexes of cyclin-dependent kinases (CDK) 4 and 6, and cyclin D. This binding inhibits the kinase activity of the enzyme, which arrests the cell cycle in the Gl phase (Fig. 1). Mutant $\mathrm{p} 16^{\mathrm{CDKN2A}}$ is unable to form stable complexes with the enzyme and, therefore, does not effectively inhibit progression of cells through inappropriate mitotic divisions. The importance of this protein as a cell-cycle regulator is demonstrated by the wide array of tumor types in which mutations of $C D K N 2 A$ have been observed.

\section{IDENTIFICATION OF CDKN2A AS A POSSIBLE TUMOR SUPPRESSOR GENE}

Molecular cytogenetic studies revealed frequent heterozygous and homozygous deletions of the chromosome 9p21-p22 region in melanoma and other cell lines $(6,7)$. Linkage to markers from 9p13-p22 was reported in melanoma kindreds from the United States $(8,9)$, Australia (10), Holland (11), and the United Kingdom (12). $C D K N 2 A$ mutations were subsequently reported in several families within each cohort. However, there appear to be some families that are linked to 9p21 in which mutations in CDKN2A or the closely related adjacent gene, $C D K N 2 B(p 15)$, have not been found.

Homozygous deletions and intragenic mutations in CDKN2A are often observed in human cell lines. Initially, there was some controversy over the significance of these alterations, since they were detected far less frequently in corresponding primary tumors showing $\mathrm{LOH}$ at $9 \mathrm{p} 21$ (1,13-15). This discrepancy suggested that another tumor suppressor gene is the target of $\mathrm{LOH}$ in the region or simply that $C D K N 2 A$ is important for the maintenance of viability in cell culture. The issue has been clarified to some extent by two recent discoveries that suggest that $\mathrm{LOH}$ at 9p21 may be accounted for by previously undetected mutations in CDKN2A. First, microdeletions (spanning less than 200 kilobases and encompassing $C D K N 2 A$ ) are present; these are, however, only detectable using an array of microsatellites close to the gene and have been confirmed by fluorescent in situ hybridization (FISH) (16). Secondly, CDKN2A can be inactivated by methylation of the $\mathrm{CpG}$ island $5^{\prime}$ of the coding region (17-19). The involvement of several mechanisms in $C D K N 2 A$ inactivation has been shown in a comprehensive analysis of 29 primary head and neck squamous cell carcinomas. By immunohistochemistry, 24 of the cancers showed absence of nuclear staining. Of these 24 cancers, 16 had homozygous deletions of $C D K N 2 A, 5$ had CpG methylation, 1 had a genomic rearrangement, and another had a frameshift mutation in exon $1(20)$.

\section{GERMLINE MUTATIONS}

Germline mutations in $C D K N 2 A$ reported to date are primarily point mutations (Fig. 2). They are observed in FAMMM families but also in cancerprone kindreds which do not fit the criteria for FAMMM.

\section{Familial Atypical Multiple Mole/Melanoma (FAMMM)}

Germline mutations in $C D K N 2 A$ have been reported in FAMMM pedigrees that show linkage to chromosome $9 \mathrm{p}$. Hussussian et al. described eight $C D K N 2 A$ germline substitutions observed in 13 of 18 American FAMMM kindreds (21). Of these, six are probably disease-related mutations since they were identified in 33 out of 36 melanoma cases in nine families. The remaining two 


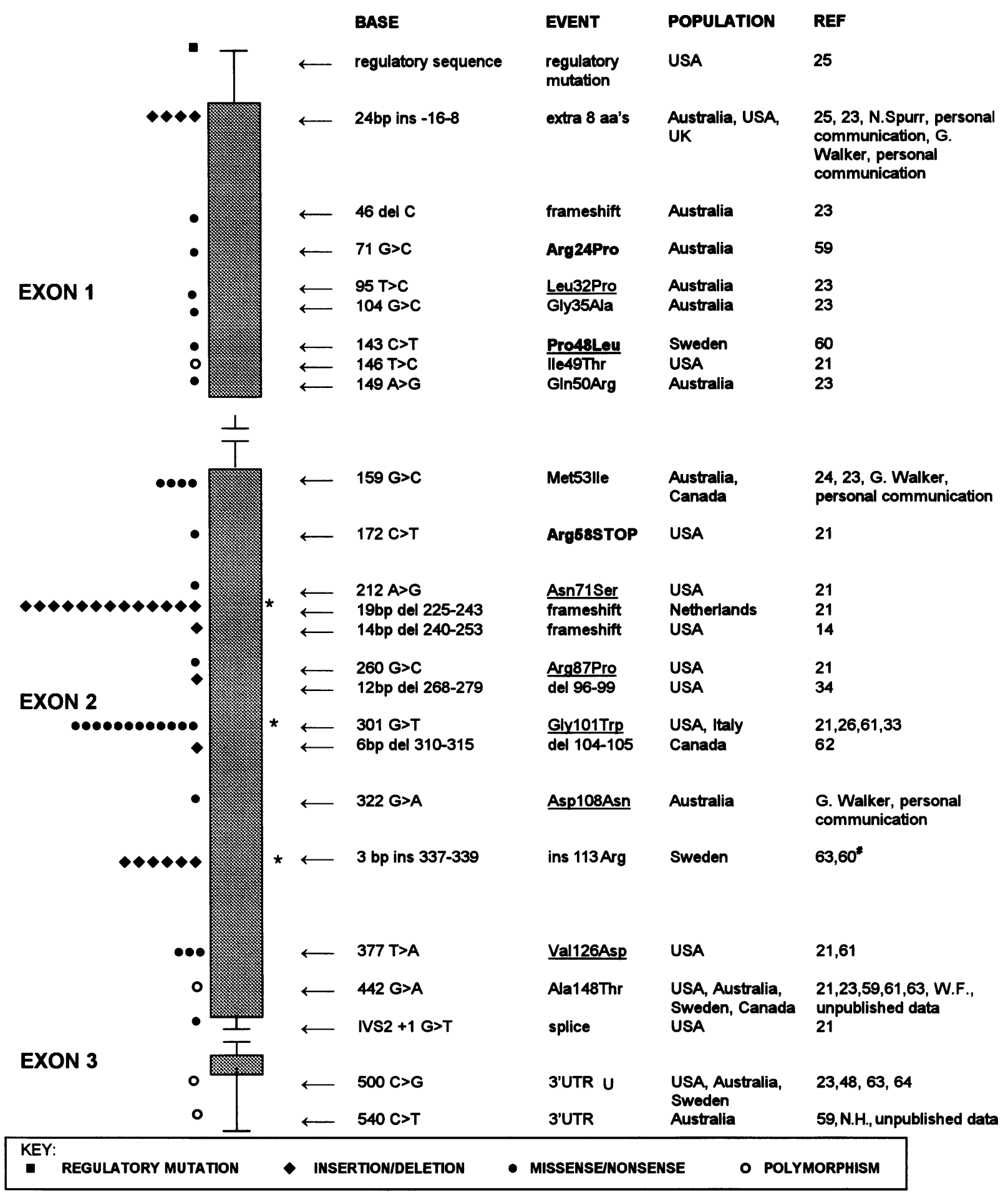

FIG. 2. Germline mutations and polymorphisms in CDKN2A identified to date (July 1996) and their relative frequencies

Although the $C D K N 2 A$ germline variants are presented here in melanoma kindreds, this term does not apply to all of the families listed here: the Met53lle (23), Glyl01Trp (33), and 12 bp del 268-279 (34) have all been reported to occur in kindreds with only one case of melanoma. Each symbol to the left of the diagram represents one family in which the corresponding mutation has been found. Underlined mutations occur in consensus ankyrin domain amino acids. Mutations in bold are also seen somatically in primary tumors and/or cell lines. Mutations accompanied by asterisks have some kindred sharing a common founder. \#In the original reference, this mutation was reported as Ins111 Arg. This is probably the same mutation as the Ins113Arg reported by Borg et al. (63). 
were detected in normal controls and are thought to be nondeleterious polymorphisms.

A 19 base pair germline deletion in CDKN2A was detected in 13 of 15 Dutch FAMMM kindreds (22). This deletion is a founder mutation; the 13 families all originate from the same geographic region and share a common haplotype. CDKN2A mutations were not found in two other Dutch melanoma families. Two individuals from one of the families carrying the $19 \mathrm{bp}$ deletion were homozygous for the mutation. One of these individuals had three mildly atypical nevi and died at the age of 54 from adenocarcinoma originating from an unknown primary site and the other was diagnosed with melanoma in situ at age 15 . The fact that these two homozygous individuals did not have more severe phenotypes than their heterozygous relatives suggests that there may be redundancy that compensates for the lack of $\mathrm{p} 16^{\mathrm{CDKN} 2 A}$ activity.

The Met53Ile mutation (Fig. 2) could also be a founder mutation, since the antecedents of the three Australian melanoma kindreds reported with this mutation all originally lived in Scotland (23) and another report of a family with this mutation identified the place of origin as the west of Scotland (24), although this family does not fit the FAMMM criteria. Haplotype analyses are now underway but have yet to be completed.

\section{CDKN2A, FAMMM, and Pancreatic Cancer}

Pancreatic adenocarcinoma is probably the second commonest cancer in FAMMM families. The observed/expected ratio for the frequency of pancreatic cancer among 200 individuals from nine FAMMM families was $13.4(P<0.001)(3)$. In several chromosome 9p-linked FAMMM families, a mutation in $C D K N 2 A$ was found to cosegregate with both melanoma and pancreatic adenocarcinoma $(21,22,25)$. However, this risk may be limited to a subset of families. In families where the $C D K N 2 A$ mutation impaired the function of the corresponding protein (pl6M) in vitro, the risk of pancreatic cancer was increased 13-fold (standardized incidence ratio: 13.1, 95\% CI, 1.5-47.4), whereas no cases of pancreatic cancer were found in families with CDKN2A mutations that did not affect the function of the protein $(\mathrm{pl} 6 \mathrm{~W})$ in the assay used by this group (25).

The study of Ciotti et al. supports the association of pl6M mutations and pancreatic cancer risk in FAMMM families (26). They detected a Gly 101Trp missense mutation in seven Italian melanoma-prone kindreds (presumably derived from a common founder) having a combined total of three pancreatic cancers. This mutation affected the function of the $\mathrm{p} 16^{C D K N 2 A}$ protein in vitro, and was associated with increased cancer risk (27). Seven pl6W melanoma-prone kindreds, on the other hand, had a total of 18 cases of melanoma, 4 cases of dysplastic naevi, and 9 cancers at other sites, but no cases of pancreatic cancer (26).

However, this excess of pancreatic cancer in FAMMM families may be attributed, in part, to ascertainment bias. Investigations of the tumor spectrum of the FAMMM syndrome revealed no excess of pancreatic tumors in a total of 15 FAMMM kindreds and 370 individuals diagnosed with melanoma (28-30). The results from Australian kindreds (N.H., unpublished data) support this lack of excess of pancreatic cancer in FAMMM pedigrees: they found one case of pancreatic cancer in 11 families with pl6M mutations (0.4 cases expected). This difference is not significant (95\% CI, 0.49-24.56). Overall, there were slightly more cancers of all types among these families than among those with pl6W CDKN2A mutations, but again, this difference was not significant.

It may be that the risk of pancreatic cancer is related to the position or type of $C D K N 2 A$ mutation; in von Hippel Lindau disease kindreds, the risk of pheochromocytoma appears to be greatest in those with missense mutations in VHL (31), and in hereditary breast cancer, the risk of ovarian cancer may depend upon the position of the mutation along the BRCAl gene (32).

\section{CDKN2A Mutations in Melanoma Families Apparently Not Linked to 9p}

Because of the high phenocopy rate, mutations have also been reported in families inconclusive for linkage to $9 p(21,23)$. Some cases of melanoma observed in these families appear to be sporadic in origin and, in contrast to the definitively 9p-linked families, $C D K N 2 A$ mutants in these unlinked kindreds did not always segregate with the melanomas.

\section{Non-FAMMM Kindreds with CDKN2A Mutations}

$C D K N 2 A$ mutations are not restricted to the FAMMM syndrome. Interestingly, however, there are no reported mutations in families with multiple cancers that do not include melanoma. 
A family in which pancreatic cancer was the predominant cancer has been reported (33). A pl6M missense mutation (Gly 101Trp) was found in all affected family members, but only one individual was affected with melanoma (followed by pancreatic cancer). Sun et al. detected a Met53Ile $C D K N 2 A$ mutation in a non-FAMMM family with an excessive number of cancers. One member of the family developed two cutaneous malignant melanomas during pregnancy, but no other individuals have had melanomas or dysplastic nevi. A p16M (deletion of amino acids 96-99) mutation was reported in a family with melanoma, nonsmall cell lung cancer, and squamous cell carcinoma of the head and neck (34). It appears that $C D K N 2 A$ is highly penetrant for cutaneous malignant melanoma, and the absence of this cancer in a pedigree with multiple cases of other cancers is likely to imply that a CDKN2A mutation is not present in that family (W.F., unpublished data).

\section{SOMATIC MUTATIONS}

$C D K N 2 A$ is frequently homozygously deleted in cell lines derived from a number of tumor types $(13,16,35)$. In melanoma cell lines where one copy of the gene is absent, the remaining copy is frequently mutated (7). The majority of point mutations observed are nonsense, missense, or frameshift mutations. Details of the coding effect of $C D K N 2 A$ mutations can be found in a recent review by Pollock et al. (36). We have built upon the databases compiled by Pollock et al. (36) and Smith-Sorensen and Hovig (37) of CDKN2A somatic mutations in cell lines and in primary tumors, and present updated lists (to July 1996) in Tables 1 and 2, respectively.

It is interesting to note that alterations have been reported to occur in at least $70 \%$ of the possible 156 codons making up this small gene (deletions affecting more than one codon were counted only once). Moreover, only $11 \%$ of the germline mutations identified to date (Fig. 2) have been seen somatically (in either primary tumors or cell lines). There are several possible explanations for the latter phenomenon: $(1)$ ascertainment bias-novel germline mutations may be detected in kindreds displaying different phenotypes than the families tested so far; (2) deleterious mutations-certain $C D K N 2 A$ germline mutations may not be compatible with life; (3) somatic mutations reflect mutagenesis by a different carcinogen (i.e., ultraviolet radiation in- duces characteristic transitions and tandem base changes); and, (4) the lack of concordance between somatic and germline mutations may be attributed to chance.

\section{Homozygous Deletions in Cell Lines}

There have been numerous reports of homozygous deletion of the $9 \mathrm{p} 21$ region in cell lines derived from a wide variety of human tumors $(7,35)$. CDKN2A has often (but not always) proven to be the target of these deletions. If a gene is the sole target of homozygous deletion, one would expect to find intragenic mutations in the DNA of cell lines without homozygous deletions. This criterion is not always met in the case of $C D K N 2 A$, however, which suggests the presence of another gene in the region that is responsible for the deletions observed; the neighboring $C D K N 2 B$ gene is an obvious candidate. Microdeletions, aberrant $\mathrm{CpG}$ island methylation, or other regulatory mutations in $C D K N 2 A$ not detected by the assays used by these investigators, may account for part of the reported absence of homozygous deletions (see above).

Cell lines with deletions of $C D K N 2 A$ alone, $C D K N 2 B$ alone, and with codeletion of the two genes have all been observed $(2,13,38-45)$. $C D K N 2 A$ is usually but not always included in the smallest region of homozygous deletion $(2,38,39,46)$. This result can be interpreted in various ways: (1) the target gene is CDKN2A in some cases and $C D K N 2 B$ in others; (2) both genes together are the target of the deletions; or (3) other tumor suppressor genes are present in the region. Jen et al. (38) favor the "double target" hypothesis because the protein products of the two genes appear to have analogous biochemical activities and the region of homozygous deletion most often contains both genes. A more definitive explanation awaits further functional analyses of the genes, especially CDKN2B.

\section{Common Tumors with a Low Frequency of CDKN2A Mutations}

COLON CARCINOMA. CDKN2A mutations are rarely observed in colon cancer $(7,13,16,38)$. Interestingly, aberrant $5^{\prime} \mathrm{CpG}$ island methylation associated with loss of transcription of CDKN2A occurs frequently in both colon cancer cell lines and primary colon tumors (18). Of all the cell lines tested, those derived from colon primaries showed the highest frequency of de novo meth- 
ylation (92\%). CpG island methylation accompanied by transcriptional silencing of $C D K N 2 A$ was also observed in the normal colonic mucosa of individuals with and without cancer (19). It is uncertain whether this uncommon situation represents a precancerous state or normal cell function. In general, these data point to hypermethylation as an alternative mechanism of $C D K N 2 A$ inactivation in colon cancer.

BREAST CANCER. CDKN2A is homozygously deleted in $60-65 \%$ of primary breast tumors and cell lines $(7,16)$, however point mutations in this malignancy are rare (Tables 1 and 2). Of 24 primary breast carcinomas analyzed by Brenner et al., 58\% showed LOH or allelic imbalance at 9 p21-22, but only 1 of 21 had an intragenic mutation (47). Xu et al. screened 37 primary breast carcinomas and 5 cell lines for alterations in $C D K N 2 A$ by single-strand conformation analysis (SSCA) (48). No mutations were found in any of the tumor samples but the gene was homozygously deleted in 2 of the 5 cell lines. Herman et al. reported $\mathrm{CpG}$ island methylation in $33 \%$ of breast cancer cell lines (18). Thus, it would appear that the primary mechanisms of CDKN2A inactivation in breast cancer are homozygous deletion and hypermethylation, but not point mutation.

OVARIAN CARCINOMA. LOH at 9p21 has been observed in $29-48 \%$ of ovarian tumors and cell lines $(7,49)$; however, no tumor-specific $C D K N 2 A$ mutations were detected in a total of 78 primary ovarian tumors analyzed by Campbell et al. (49) and Hatta et al. (50), and homozygous deletions were seen in only 2 tumors. It is not clear whether the high rate of $9 \mathrm{p}$ allelic loss in this malignancy is due to mechanisms of $C D K N 2 A$ inactivation other than deletions and point mutations, or whether a different tumor suppressor gene is the target of $\mathrm{LOH}$. There is an interesting parallel on chromosome $18 \mathrm{q}$, where $\mathrm{LOH}$ is extremely frequent in colon cancer. At first, the gene DCC (51) was thought to be the sole target of the $\mathrm{LOH}$, but it is now apparent that DPC4 and another related gene, $J V$-18-1, may also be mutated or otherwise inactivated in colorectal cancers $(52,53)$. Similarly, perhaps other 9p21 cancer genes await identification.

The frequency of intragenic mutations in CDKN2A is relatively low in uncultured tumors. However, since there are other ways of abrogating $\mathrm{p} 16^{C D K N 2 A}$ function, the frequency of inactivation of $C D K N 2 A$ in a given tumor type may in fact be higher than might be predicted from se- quence analysis only. If this is the case, overall, $C D K N 2 A$ may be somatically altered at a similar frequency to $p 53$.

\section{CDKN2A Mutations, Expression Levels, and Survival}

Loss of $\mathrm{p} 16^{\mathrm{CDKN2A}}$ expression may be related to invasiveness or metastatic potential rather than to tumor initiation. This is supported by the study of Reed et al. (54), who performed immunohistochemical analysis of p16 $6^{C D K N 2 A}$ expression on 103 melanocytic lesions ranging from atypical nevi to metastatic melanomas. p16 ${ }^{C D K N 2 A}$ expression was detected in $100 \%$ of atypical nevi and melanomas in situ and in $91 \%$ of primary invasive melanomas, but in only $56 \%$ of metastatic melanomas.

Nearly $80 \%$ of pancreatic cell lines or xenografts $(55)$ and $37 \%$ of primary pancreatic adenocarcinomas (56) have $C D K N 2 A$ mutations or deletions. The status of $C D K N 2 A$ may be related to the prognosis of pancreatic cancer patients: mean survival was 13.5 months longer for individuals with $C D K N 2 A$ mutation-negative tumors compared with those having mutation-positive tumors $(p=0.017)$ (57). It is interesting that LOH at 9p21 in breast cancers, on the other hand, may not confer an adverse prognosis (58). Thus it may be that the poorer survival in pancreatic carcinomas with $C D K N 2 A$ mutations is either because $C D K N 2 A$ mutations have a tumorspecific effect, or because in breast cancer, another gene is the target for the $\mathrm{LOH}$ and this gene does not have an adverse effect on survival.

\section{CONCLUSIONS}

Over the last 2 years, $C D K N 2 A$ has been the subject of intensive research. It clearly plays a central role in the development of both hereditary and sporadic forms of melanoma. The gene is frequently altered in tumors of many different types, although its importance in most of these cancers can only be inferred. Future reviews of $C D K N 2 A$ will hopefully focus on attempts to further dissect its function and to rectify the defects in vivo.

\section{ACKNOWLEDGMENTS}

We thank Sophie Sun for her contribution to the tables and figures. WDF is supported by grants from Fonds de la recherche en Santé du Québec and the Cancer Research Society of Canada. 
TABLE 1. CDKN2A Somatic mutations identified to date (July 1996) in cell lines

\begin{tabular}{|c|c|c|c|}
\hline Base & Event/Codon & Cell Line & Reference \\
\hline \multicolumn{4}{|l|}{ Exon 1} \\
\hline 25 ins TG & 9 & Pancr adeno & 44 \\
\hline $35 \mathrm{C}>\mathrm{A}$ & Ser12STOP & NSCLC & 41 \\
\hline 55 ins CGCGCAC & 19 & Ductal pancr & 42 \\
\hline 58 ins ACGGCC & 20 & Pancr adeno & 36 \\
\hline $58 \mathrm{G}>\mathrm{C}$ & Ala20Pro & Melanoma, lung & 36 \\
\hline 63 del $23 \mathrm{bp}$ & 21 & Liver & 36 \\
\hline ? ins $1 \mathrm{bp}$ & 23 & Colon & 36 \\
\hline 85 del 18 bp & 29 & Pancr adeno & 42 \\
\hline $101 \mathrm{del} C G \mathrm{G}$ & 34 & Ductal pancr & 42 \\
\hline $104 \mathrm{G}>\mathrm{A}$ & Gly35Glu & Melanoma & 36 \\
\hline $106 \mathrm{G}>\mathrm{A}$ & Ala36Thr & Pancr adeno & 44 \\
\hline 128 del GT & 43 & Melanoma & 36 \\
\hline 131 del $33 \mathrm{bp}$ & 44 & Lung mucoepidermoid & 36 \\
\hline $134 \mathrm{del} \mathrm{G}$ & 45 & NSCLC SCC & 36 \\
\hline $142 \mathrm{CC}>\mathrm{TT}$ & Pro48Leu & Melanoma & 36 \\
\hline $143 \mathrm{C}>\mathrm{T}$ & $\underline{\text { Pro48Leu }}$ & Melanoma & 36 \\
\hline$\underline{148 \mathrm{C}>\mathrm{T}}$ & Gln50STOP & Melanoma & 36 \\
\hline int $1-2 \mathrm{~A}>\mathrm{C}$ & splice & Chondrosarcoma, NPC & 36 \\
\hline intl-2 $A>G$ & splice & Mesothelioma & 36 \\
\hline int $1-1 \mathrm{G}>\mathrm{T}$ & splice & HNSCC & 36 \\
\hline intl-1 G>A & splice & NPC & 36 \\
\hline \multicolumn{4}{|l|}{ Exon 2} \\
\hline$\underline{155 \mathrm{~T}>\mathrm{A}}$ & Met52Lys & Ductal pancr & 42 \\
\hline $156 \mathrm{G}>\mathrm{C}$ & Met52Ile & Breast & 65 \\
\hline 161 del $14 \mathrm{bp}$ & 54 & Oral SCC & 36 \\
\hline 167 ins $1 \mathrm{bp}$ & 56 & Melanoma & 36 \\
\hline $171 \mathrm{C}>\mathrm{A}$ & Ala57Ala & Melanoma & 36 \\
\hline $171 \mathrm{CC}>\mathrm{TT}$ & Arg58STOP & Melanoma & 36 \\
\hline $172 \mathrm{C}>\mathrm{T}$ & $\underline{\text { Arg58STOP }}$ & Bladder, melanoma & 36 \\
\hline 172 del 8 bp & 58 & Melanoma & 36 \\
\hline 174 del 16 bp & 58 & Oral SCC & 36 \\
\hline 180 del 29 bp & 60 & T-ALL & 66 \\
\hline 180 ins $1 \mathrm{bp}$ & 60 & Melanoma & 36 \\
\hline $181 \mathrm{G}>\mathrm{T}$ & $\underline{\text { Glu61STOP }}$ & Melanoma & 36 \\
\hline $182 \mathrm{~A}>\mathrm{G}$ & Glu61Gly & Pancr adeno & 44 \\
\hline $183 \mathrm{G}>\mathrm{C}$ & Glu61 Asp & Oral SCC & 67 \\
\hline $184 C>G$ & Leu62Val & Oral SCC & 67 \\
\hline 199 ins $1 \mathrm{bp}$ & 67 & Melanoma & 36 \\
\hline 204 del 5 bp & 68 & Thyroid & 68 \\
\hline$\underline{205 \mathrm{G}>\mathrm{T}}$ & Glu69STOP & Melanoma, NSCLC & 36,41 \\
\hline $206 \mathrm{~A}>\mathrm{T}$ & Glu69Val & NSCLC SCC & 36 \\
\hline $207 \mathrm{G}>\mathrm{C}$ & Glu69Asp & Oral SCC & 67 \\
\hline $208 \mathrm{C}>\mathrm{G}$ & Pro70Ala & Oral SCC & 67 \\
\hline
\end{tabular}


TABLE 1. (Continued)

\begin{tabular}{|c|c|c|c|}
\hline Base & Event/Codon & Cell Line & Reference \\
\hline $216 \mathrm{C}>\mathrm{A}$ & Cys72STOP & NSCLC & 41 \\
\hline$\underline{220 \mathrm{G}>\mathrm{A}}$ & Asp74Asn & Bladder & 36 \\
\hline 231 del TCTC & 77 & Oral SCC & 36 \\
\hline $233^{a} \underline{\mathrm{del} T C}$ & $\underline{78}$ & Pancr adeno, bladder, oral SCC & 36,37 \\
\hline $237 \mathrm{CC}>\mathrm{TT}$ & Arg80STOP & Melanoma, liposarcoma & 36,40 \\
\hline $238 \mathrm{C}>\mathrm{T}$ & Arg80STOP & $\begin{array}{l}\text { Melanoma, myeloid leukemia, T- } \\
\text { ALL, Thyroid, Oral SCC }\end{array}$ & $36,67-69$ \\
\hline $242 \mathrm{C}>\mathrm{T}$ & Pro81Leu & Melanoma & 36 \\
\hline $247 \mathrm{C}>\mathrm{T}$ & His83Tyr & Melanoma, NSCLC & 36,70 \\
\hline$\underline{250 \mathrm{G}>\mathrm{T}}$ & Asp84Tyr & Prostate & 36 \\
\hline $261 \mathrm{GG}>\mathrm{AA}$ & Glu88Lys & Melanoma & 36 \\
\hline$\underline{262 \mathrm{G}>\mathrm{A}}$ & Glu88Lys & Melanoma & 36 \\
\hline $262 \mathrm{G}>\mathrm{T}$ & Glu88STOP & Melanoma & 36 \\
\hline $264 \mathrm{GG}>\mathrm{AA}$ & Gly89Ser & Melanoma & 36 \\
\hline 290 & $5 b p$ del 97 & Melanoma & 36 \\
\hline 295 & 3bp del 99 & Melanoma & 36 \\
\hline $296 \mathrm{GG}>\mathrm{CA}$ & Arg99Pro & Melanoma & 36 \\
\hline$? \mathrm{G}>\mathrm{A}$ & 101 & Leukemia & 71 \\
\hline $320 \mathrm{G}>\mathrm{A}$ & Arg 107His & Leukemia & 71 \\
\hline $322 \mathrm{G}>\mathrm{C}$ & Aspl08His & Bladder & 36 \\
\hline $329 \mathrm{G}>\mathrm{A}$ & Trp1 10STOP & Melanoma & 36 \\
\hline $330 \mathrm{G}>\mathrm{A}$ & Trpl10STOP & Melanoma, ovary & 36 \\
\hline $335 \mathrm{G}>\mathrm{C}$ & Arg 1 12Pro & Melanoma & 36 \\
\hline$\underline{341 \mathrm{C}>\mathrm{T}}$ & Prol 14Leu & Melanoma, fibrosarcoma & 36 \\
\hline $346 \mathrm{G}>\mathrm{T}$ & Aspl16Tyr & Melanoma & 40 \\
\hline$\underline{358 \mathrm{G}>\mathrm{T}}$ & Glu120STOP & Oral SCC & 67 \\
\hline ? del & 122 & Leukemia & 71 \\
\hline$? \mathrm{G}>\mathrm{C}$ & 122 & Leukemia & 71 \\
\hline $369 \mathrm{~T}>\mathrm{A}$ & His 123Gln & NSCLC & 41 \\
\hline $378 \mathrm{C}>\mathrm{T}$ & Val126Val & Melanoma & 36,72 \\
\hline $386 \mathrm{~A}>\mathrm{G}$ & Tyr129Cys & Pancr adeno & 44 \\
\hline $425 \mathrm{~A}>\mathrm{G}$ & His 142Arg & Melanoma & 36 \\
\hline int $2+1 \mathrm{G}>\mathrm{T}$ & splice & NSCLC & 36 \\
\hline int $2+2 \mathrm{~T}>\mathrm{C}$ & splice & Ductal pancr & 55 \\
\hline
\end{tabular}

Underlined mutations appear in both cell lines and primary tumors. Question marks indicate information not specified in the original sources. The following abbreviations appear in the tables: pancr, pancreas; adeno, adenocarcinoma; SCC, squamous cell carcinoma; NSCLC, non-small cell lung cancer; NPC, nasopharyngeal carcinoma; HNSCC, head and neck squamous cell carcinoma (HNC, head and neck cancer); T-ALL, T-lymphocyte acute lymphoblastic leukemia. Since we have built upon the databases of $C D K N 2 A$ somatic mutations compiled by Pollock et al. (36) and Smith-Sorensen and Hovig (37), we do not quote the primary sources for most of the mutations reported in these two publications. Please see these reviews for the original references. ${ }^{a}$ Because of the ambiguity involved in assigning nucleotide positions to certain deletions, this deletion is numbered from where the wild-type sequence first changes. 
TABLE 2. CDKN2A somatic mutations identified to date (July 1996) in primary tumors

\begin{tabular}{|c|c|c|c|}
\hline Base & Event/Codon & Tumor & Reference \\
\hline \multicolumn{4}{|l|}{ Exon 1} \\
\hline$?-17$ del $24 \mathrm{bp}$ & $1-3$ & Prostate & 36 \\
\hline ? ins $\mathrm{C}$ & 4 & Melanoma & 73 \\
\hline 15 del 37 bp & 5 & Pancr adeno ${ }^{a}$ & 36 \\
\hline 23 del GCATGGA & 8 & ALL & 74 \\
\hline \multicolumn{4}{|l|}{ /insTCCCGG } \\
\hline $27 \mathrm{G}>\mathrm{A}$ & Met9lle & Hilar bile duct & 36 \\
\hline 33 del 35 bp & 11 & B-NHL & 75 \\
\hline $42 \mathrm{C}>\mathrm{G}$ & Asp 14Glu & Gall bladder & 36 \\
\hline 47 del 4 bp & 16 & Pancr adeno ${ }^{a}$, esoph SCC, glioblastoma & $55,76,77$ \\
\hline $47 \mathrm{~T}>\mathrm{C}$ & Leu 16Pro & Hilar bile duct & 36 \\
\hline 52 del 32 bp & 18 & Pancr adeno & 56 \\
\hline $57 \mathrm{del} \mathrm{C}$ & 19 & NSCLC & 78 \\
\hline $58 \mathrm{G}>\mathrm{T}$ & Ala20Ser & Gall bladder & 36 \\
\hline $59 \mathrm{C}>\mathrm{A}$ & Ala20Glu & NSCLC & 70 \\
\hline $68 \mathrm{del} \mathrm{G}$ & 23 & NSCLC & 78 \\
\hline $68 \mathrm{G}>\mathrm{A}$ & Gly23Asp & Pancr $^{a}$ & 36 \\
\hline $71 \mathrm{G}>\mathrm{C}$ & Arg24Pro & Sarcoma & 45 \\
\hline $74 \mathrm{~T}>\mathrm{C}$ & Val25Ala & Prostate & 79 \\
\hline $78 \mathrm{G}>\mathrm{C}$ & Glu26Asp & Gall bladder & 36 \\
\hline$?$ del 21 bp & 29 & Pancr adeno & 56 \\
\hline $88 \mathrm{G}>\mathrm{C}$ & Ala30Pro & Esoph SCC & 36 \\
\hline $97 \mathrm{G}>\mathrm{T}$ & Glu33STOP & HNSCC & 36 \\
\hline $99 \mathrm{G}>\mathrm{T}$ & Glu33Asp & Hilar bile duct & 36 \\
\hline $109 \mathrm{C}>\mathrm{T}$ & Leu37Leu & Melanoma & 80 \\
\hline $124 \mathrm{~A}>\mathrm{G}$ & Asn42Asp & Ductal pancr & 42 \\
\hline $132 \mathrm{C}>\mathrm{A}$ & Tyr44STOP & NSCLC & 36 \\
\hline $143 \mathrm{C}>\mathrm{T}$ & Pro48Leu & HNSCC & 36 \\
\hline $146 \mathrm{~T}>\mathrm{G}$ & Ile49Ser & Hilar bile duct & 36 \\
\hline $148 \mathrm{C}>\mathrm{T}$ & Gln50STOP & Esoph SCC & 76 \\
\hline $150 \mathrm{GG}>\mathrm{CC}$ & $\begin{array}{l}\text { Gln50 His/ } \\
\text { Val51Leu }\end{array}$ & Melanoma & 81 \\
\hline intl-1 $\mathrm{G}>\mathrm{T}$ & splice & NSCLC SCC & 82 \\
\hline int $1-8$ del $27 \mathrm{bp}$ & splice & CLL & 83 \\
\hline int $1-9$ del $61 \mathrm{bp}$ & splice & Bladder & 36 \\
\hline int $1-2 \mathrm{~A}>\mathrm{T}$ & splice & Bladder & 36 \\
\hline \multicolumn{4}{|l|}{ Exon 2} \\
\hline $151 \mathrm{G}>\mathrm{A}$ & Val51lle & Ductal pancr & 42 \\
\hline $152 \mathrm{~T}>\mathrm{A}$ & Val5lAsp & Pancr adeno & 36 \\
\hline $155 \mathrm{~T}>\mathrm{A}$ & $\underline{\text { Met52Lys }}$ & Breast & 36 \\
\hline 157 del A & 53 & Bladder & 36 \\
\hline $158 \mathrm{~T}>\mathrm{C}$ & Met53Thr & CLL & 83 \\
\hline 160 del A & 54 & Pancr adeno & 56 \\
\hline $164 \mathrm{del}$ G & 55 & Esoph SCC & 36 \\
\hline
\end{tabular}


TABLE 2. (Continued)

\begin{tabular}{|c|c|c|c|}
\hline Base & Event/Codon & Tumor & Reference \\
\hline 165 ins $1 \mathrm{bp}$ & 55 & Endomet & 36 \\
\hline $166 \mathrm{del}$ AG & 56 & NSCLC SCC & 36 \\
\hline 169 del 13 & 57 & B-NHL & 75 \\
\hline $171 \mathrm{del} \mathrm{CC}$ & 57 & Ductal pancr & 42 \\
\hline $170 \mathrm{C}>\mathrm{T}$ & Ala57Val & ALL & 36 \\
\hline $172 \mathrm{C}>\mathrm{T}$ & Arg58STOP & Esoph SCC, bladder, NSCLC SCC, pancr adeno & 56,82 \\
\hline 174 ins $7 \mathrm{bp}$ & 58 & T-ALL & 66 \\
\hline 176 ins $\mathrm{G}$ & 59 & NSCLC adeno & 36 \\
\hline$\underline{181 \mathrm{G}>\mathrm{T}}$ & Glu61STOP & Esoph SCC, HNSCC & 36 \\
\hline $192 \mathrm{del} \mathrm{GCT}$ & 64 & NSCLC SCC & 36 \\
\hline 194 del 50 bp & 65 & Esoph SCC & 36 \\
\hline $\begin{array}{l}196 \text { del } 1 \mathrm{bp} \\
\text { CAC }>\text { TA }\end{array}$ & His66STOP & Melanoma & 73 \\
\hline $196 \mathrm{C}>\mathrm{T}$ & His66Tyr & NSCLC SCC & 36 \\
\hline $202 \mathrm{G}>\mathrm{A}$ & Ala68Thr & Esoph SCC & 36 \\
\hline$\underline{205 \mathrm{G}>\mathrm{T}}$ & Glu69STOP & NSCLC & 41 \\
\hline $205 \mathrm{G}>\mathrm{A}$ & Glu69Lys & Bladder & 37 \\
\hline 213 & 71 & T-ALL & 66 \\
\hline \multicolumn{4}{|c|}{ AAC $>$ AAGGTCG } \\
\hline $214 \mathrm{~T}>\mathrm{G}$ & Cys72Gly & Esoph SCC & 36 \\
\hline 216 del C & 72 & NSCLC large cell & 82 \\
\hline $216 \mathrm{C}>\mathrm{A}$ & Cys72STOP & NSCLC & 41 \\
\hline $217 \mathrm{G}>\mathrm{A}$ & Ala73Thr & Glioblastoma & 84 \\
\hline$\underline{220 \mathrm{G}>A}$ & Asp74Asn & Esoph SCC & 36 \\
\hline $221 \mathrm{~A}>\mathrm{T}$ & Asp74Val & Hepatic bile duct & 36 \\
\hline $224 \mathrm{C}>\mathrm{T}$ & Pro75Leu & Breast & 85 \\
\hline $226 \mathrm{G}>\mathrm{A}$ & Ala76Thr & Esoph SCC & 36 \\
\hline $227 \mathrm{C}>\mathrm{T}$ & Ala76Val & Glioblastoma & 84 \\
\hline$\underline{233 \# \text { del TC }}$ & $\underline{78}$ & T-ALL & 86 \\
\hline$\underline{238 \mathrm{C}>\mathrm{T}}$ & $\underline{\operatorname{Arg} 80 S T O P}$ & $\begin{array}{l}\text { Esoph SCC, NSCLC SCC, bladder, T-ALL, pancr }{ }^{a} \text {, } \\
\text { oral SCC }\end{array}$ & $36,56,67,86$ \\
\hline 239 del G & 80 & Esoph SCC, B-NHL & 36,75 \\
\hline $239 \mathrm{G}>\mathrm{T}$ & Arg80Leu & HNSCC & 36 \\
\hline$\underline{242 \mathrm{C}>\mathrm{T}}$ & $\underline{\text { Pro81Leu }}$ & Melanoma, thyroid & 36,87 \\
\hline 243 ins 19 bp & 82 & Pancr adeno & 56 \\
\hline $247 \mathrm{C}>\mathrm{A}$ & His83Asn & NSCLC SCC & 36 \\
\hline $247 \mathrm{C}>\mathrm{T}$ & His83Tyr & HNSCC, pancr ${ }^{a}$, breast & 36 \\
\hline $250 \mathrm{G}>\mathrm{A}$ & Asp84Asn & Esoph SCC, NSCLC adeno, HNSCC & 36 \\
\hline $250 \mathrm{G}>\mathrm{C}$ & Asp84His & NSCLC adeno & 36 \\
\hline $250 \mathrm{G}>\mathrm{T}$ & $\underline{\text { Asp84Tyr }}$ & NSCLC SCC & 36 \\
\hline $252 \mathrm{C}>\mathrm{A}$ & Asp84Glu & Bladder & 37 \\
\hline $253 \mathrm{G}>\mathrm{A}$ & Ala85Thr & Glioblastoma & 84 \\
\hline 257 ins $\mathrm{G}$ & 86 & NSCLC large cell & 36 \\
\hline$\underline{262 \mathrm{G}>\mathrm{T}}$ & Glu88STOP & NSCLC SCC, melanoma & 81,82 \\
\hline $264 \mathrm{G}>\mathrm{T}$ & Glu88Asp & Gall bladder & 36 \\
\hline 266 del GC & 89 & $\mathrm{HCC}$ & 88 \\
\hline
\end{tabular}


TABLE 2. (Continued)

\begin{tabular}{|c|c|c|c|}
\hline Base & Event/Codon & Tumor & Reference \\
\hline 27l\# del C & 91 & Pancr adeno ${ }^{a}$, bladder & 36,89 \\
\hline $274 \mathrm{del} \mathrm{G}$ & 92 & NSCLC SCC & 36 \\
\hline $277 \mathrm{~A}>\mathrm{G}$ & Thr93Ala & NSCLC adeno & 36 \\
\hline $278 \mathrm{C}>\mathrm{G}$ & Thr93Arg & Glioma & 36 \\
\hline $284 \mathrm{~T}>\mathrm{C}$ & Val95Ala & NSCLC adeno & 36 \\
\hline $292 \mathrm{C}>\mathrm{T}$ & His98Tyr & Glioblastoma & 84 \\
\hline $293 \mathrm{AC}>\mathrm{CT}$ & His98Pro & Melanoma & 36 \\
\hline $293 \mathrm{~A}>\mathrm{G}$ & His98Arg & CLL & 83 \\
\hline $294 \mathrm{C}>\mathrm{A}$ & His98Leu & Melanoma & 36 \\
\hline $296 \mathrm{G}>\mathrm{A}$ & Arg99Gln & NSCLC adeno & 36 \\
\hline $298 \mathrm{GC}>\mathrm{CT}$ & Ala 100Leu & Melanoma & 36 \\
\hline $305 \mathrm{C}>\mathrm{T}$ & Ala102Val & Glioblastoma & 84 \\
\hline 307 del CG/ins A & 103 & NSCLC SCC & 82 \\
\hline 310 del $C$ & 104 & Esoph SCC & 36 \\
\hline $313 \mathrm{del} \mathrm{G}$ & 105 & Esoph SCC & 36 \\
\hline 314 del $20 \mathrm{bp}$ & 105 & Pancr adeno ${ }^{a}$ & 36 \\
\hline $316 \mathrm{G}>\mathrm{A}$ & Vall06Met & Glioblastoma & 84 \\
\hline $319 \mathrm{C}>\mathrm{T}$ & Arg 107Cys & Glioblastoma & 84 \\
\hline $322 \mathrm{G}>\mathrm{T}$ & Asp108Tyr & HNSCC, NSCLC SCC & 82 \\
\hline $329 \mathrm{G}>\mathrm{A}$ & Trpl10STOP & Melanoma & 36 \\
\hline $330 \mathrm{G}>\mathrm{A}$ & Trpl10STOP & Melanoma, pancr ${ }^{a}$, glioma, T-ALL & 36,90 \\
\hline $332 \mathrm{G}>\mathrm{A}$ & Gly111Asp & Bladder & 89 \\
\hline $334 \mathrm{C}>\mathrm{G}$ & $\operatorname{Arg} 112$ Gly & Melanoma & 73 \\
\hline $340 \mathrm{C}>\mathrm{T}$ & Prol14Ser & Esoph SCC & 36 \\
\hline $341 \mathrm{C}>\mathrm{T}$ & Prol 14Leu & Astrocytoma & 36 \\
\hline $347 \mathrm{~A}>\mathrm{T}$ & Aspl 16Val & Prostate, CLL & 79,83 \\
\hline 350 del T & 117 & Bladder & 89 \\
\hline $352-44088$ bp del & 118 & Glioma & 84 \\
\hline $355 \mathrm{G}>\mathrm{C}$ & Glu119Gln & Gall bladder & 36 \\
\hline $358 \mathrm{G}>\mathrm{T}$ & Glu120STOP & Esoph adeno, NSCLC & 36 \\
\hline $358 \mathrm{G}>\mathrm{A}$ & Glu120Lys & NSCLC adeno, SCC & 36 \\
\hline $359 \mathrm{~A}>\mathrm{C}$ & Glu120Ala & NSCLC adeno & 36 \\
\hline $364 \mathrm{G}>\mathrm{A}$ & Gly122Ser & Ampullary & 36 \\
\hline 365 del G & 122 & NSCLC SCC & 36 \\
\hline $369 \mathrm{~T}>\mathrm{A}$ & His123Gln & CLL & 36 \\
\hline $371 \mathrm{G}>\mathrm{A}$ & Arg124His & Esoph SCC & 36 \\
\hline 374 del A & 125 & T-ALL & 86 \\
\hline $375 \mathrm{~T}>\mathrm{C}$ & Asp125Asp & Bile duct & 36 \\
\hline $378 \mathrm{C}>\mathrm{T}$ & Val126Val & Bladder & 72 \\
\hline $379 \mathrm{G}>\mathrm{T}$ & Ala127Ser & Bladder & 91 \\
\hline $380 \mathrm{C}>\mathrm{T}$ & Ala127Val & Glioblastoma & 84 \\
\hline $382 \mathrm{C}>\mathrm{T}$ & $\operatorname{Arg} 128 \operatorname{Trp}$ & Glioblastoma & 84 \\
\hline 385 del 23 bp & 129 & Pancr adeno & 56 \\
\hline $394 \mathrm{G}>\mathrm{C}$ & Ala 132Pro & NSCLC adeno & 36 \\
\hline $401 \mathrm{C}>\mathrm{T}$ & Ala134Val & NSCLC adeno & 36 \\
\hline $405 \mathrm{G}>\mathrm{A}$ & Gly135Gly & Gall bladder, glioma, NSCLC, stomach, T-ALL & $41,66,92,93$ \\
\hline
\end{tabular}


TABLE 2. (Continued)

\begin{tabular}{|c|c|c|c|}
\hline Base & Event/Codon & Tumor & Reference \\
\hline $406 \mathrm{del} \mathrm{GG}$ & 136 & Esoph SCC & 36 \\
\hline $407 \mathrm{G}>\mathrm{A}$ & Gly136Asp & Glioblastoma & 84 \\
\hline $424 \mathrm{C}>\mathrm{T}$ & His 142Tyr & NSCLC adeno & 36 \\
\hline 430 del C & 144 & Esoph SCC & 36 \\
\hline $430 \mathrm{C}>\mathrm{T}$ & Arg 144Cys & Esoph SCC & 36 \\
\hline $449 \mathrm{G}>\mathrm{T}$ & Gly150Val & NSCLC SCC & 36 \\
\hline $451 \mathrm{C}>\mathrm{T}$ & Prol51Ser & Melanoma & 80 \\
\hline int $2+1 \mathrm{G}>\mathrm{T}$ & splice & NSCLC & 41 \\
\hline int $2+2 \mathrm{~T}>\mathrm{C}$ & splice & Pancr $^{a}$ & 36 \\
\hline \multicolumn{4}{|c|}{$\begin{array}{l}\text { Underlined mutations appear in both cell lines and primary tumors. Question marks indicate information not specified in the } \\
\text { original sources. The following abbreviations appear in the tables: pancr, pancreas; esoph, esophagus; adeno, adenocarcinoma; } \\
\text { SCC, squamous cell carcinoma; ALL, acute lymphoblastic leukemia (T-ALL, T-lymphocyte ALL); CLL, chronic lymphoblastic leu- } \\
\text { kemia; NSCLC, non-small cell lung cancer; HNSCC, head and neck squamous cell carcinoma; B-NHL, B-lymphocyte non- } \\
\text { Hodgkin's lymphoma; HCC, hepatocellular carcinoma. Since we have built upon the databases of CDKN2A somatic mutations } \\
\text { compiled by Pollock et al. (36) and Smith-Sorensen and Hovig ( } 37 \text { ), we do not quote primary sources for most of the mutations } \\
\text { reported in these two publications. Please see these reviews for the original references. } \\
{ }^{a} \text { Xenograft. } \\
{ }^{b} \text { Because of the ambiguity involved in assigning nucleotide positions to certain deletions, these deletions are numbered from }\end{array}$} \\
\hline
\end{tabular}

\section{REFERENCES}

1. Cairns P, Mao L, Merlo A, et al. (1994) Rates of pl6 (MTS1) mutations in primary tumors with 9p loss. Science 265: 415-417.

2. Izumoto $S$, Arita N, Ohnishi T, Hiraga S, Taki T, Hayakawa T. (1995) Homozygous deletions of Pl6(INK4A)/MTS1 and P15 (INK4B)/MTS2 genes in glioma cells and primary glioma tissues. Cancer Lett. 97: 241247.

3. Bergman W, Watson P, de Jong J, Lynch HT, Fusaro RM. (1990) Systemic cancer and the FAMMM syndrome. Br. J. Cancer 61: 932936.

4. Hollstein $M$, Rice $K$, Greenblatt MS, et al. (1994) Database of p53 gene somatic mutations in human tumors and cell lines. $\mathrm{Nucl}$. Acids Res. 22: 3551-3555.

5. Li FP, Fraumeni JF, Jr, Mulvihill JJ, et al. (1988) A cancer family syndrome in twentyfour kindreds. Cancer Res. 48: 5358-5362.

6. Fountain JW, Karayiorgou M, Ernstoff MS, et al. (1992) Homozygous deletions within human chromosome band $9 \mathrm{p} 21$ in melanoma. Proc. Natl. Acad. Sci. U.S.A. 89: 1055710561 .
7. Kamb A, Gruis NA, Weaver-Feldhaus J, et al. (1994) A cell cycle regulator potentially involved in genesis of many tumor types. Science 264: 436-440.

8. Cannon-Albright LA, Goldgar DE, Meyer LJ, et al. (1992) Assignment of a locus for familial melanoma, MLM, to chromosome 9p13p22. Science 258: $1148-1152$.

9. Goldstein AM, Dracopoli NC, Engelstein M, Fraser MC, Clark WH, Jr, Tucker MA. (1994) Linkage of cutaneous malignant melanoma/ dysplastic nevi to chromosome 9p, and evidence for genetic heterogeneity. Am. J. Hum. Genet. 54: 489-496.

10. Nancarrow DJ, Mann GJ, Holland EA, et al. (1993) Confirmation of chromosome 9p linkage in familial melanoma. Am. J. Hum. Genet. 53: 936-942.

11. Gruis NA, Sandkuijl LA, Weber JL, et al. (1993) Linkage analysis in Dutch familial atypical multiple mole-melanoma (FAMMM) syndrome families. Effect of naevus count. Melanoma Res. 3: 271-277.

12. MacGeoch C, Bishop JA, Bataille V, et al. (1994) Genetic heterogeneity in familial ma- 
lignant melanoma. Hum. Mol. Genet. 3: 21952200.

13. Okamoto A, Demetrick DJ, Spillare EA, et al. (1994) Mutations and altered expression of pl6INK4 in human cancer. Proc. Natl. Acad. Sci. U.S.A. 91: 11045-11049.

14. Ohta M, Nagai H, Shimizu M, et al. (1994) Rarity of somatic and germline mutations of the cyclin-dependent kinase 4 inhibitor gene, CDK4I, in melanoma. Cancer Res. 54: 5269-5272.

15. Spruck $\mathrm{CH}$, 3rd, Gonzalez-Zulueta $\mathrm{M}$, Shibata A, et al. (1994) pl6 gene in uncultured tumours. Nature 370: 183-184.

16. Cairns P, Polascik TJ, Eby Y, et al. (1995) Frequency of homozygous deletion at pl6/ CDKN2 in primary human tumours. Nature Genet. 11: 210-212.

17. Merlo A, Herman JG, Mao L, et al. (1995) 5' $\mathrm{CpG}$ island methylation is associated with transcriptional silencing of the tumour suppressor pl6/CDKN2/MTS1 in human cancers. Nature Med. 1: 686-692.

18. Herman JG, Merlo A, Mao L, et al. (1995) Inactivation of the CDKN2/p16/MTS1 gene is frequently associated with aberrant DNA methylation in all common human cancers. Cancer Res. 55: 4525-4530.

19. Gonzalez-Zulueta M, Bender CM, Yang AS, et al. (1995) Methylation of the 5' CpG island of the p16/CDKN2 tumor suppressor gene in normal and transformed human tissues correlates with gene silencing. Cancer Res. 55: 4531-4535.

20. Reed AL, Califano J, Cairus $P$, Wesira WH, Jones RM, Koch W, Ahrendt S, Eby Y, Sewell D, Nawroe H, Bartek J, Sidransky D. (1996) High frequency of $p 16$ (CDKN2/MTS$1 / I N K 4 A$ ) inactivation in head and neck squamous cell carcinoma. Cancer Res. 56:3630-3633.

21. Hussussian CJ, Struewing JP, Goldstein AM, et al. (1994) Germline pl6 mutations in familial melanoma. Nature Genet. 8: 15-21.

22. Gruis NA, van der Velden PA, Sandkuijl LA, et al. (1995) Homozygotes for CDKN2 (p16) germline mutation in Dutch familial melanoma kindreds. Nature Genet. 10: 351-353.

23. Walker GJ, Hussussian CJ, Flore JF, et al. (1995) Mutations of the CDKN2/pl6(INK4) gene in Australian melanoma kindreds. Hum Mol. Genet. 4: 1845-1852.

24. Sun S, Narod SA, Foulkes WD. (1996) A pl6 mutation in a family with multiple cancers [abstract]. Eur J Hum Genet. 4: 13.
25. Goldstein AM, Fraser MC, Struewing JP, et al. (1995) Increased risk of pancreatic cancer in melanoma-prone kindreds with pl6INK4 mutations. N. Engl. J. Med. 333: 970-974.

26. Ciotti P, Strigini P, Bianchiscarra G. (1996) Familial melanoma and pancreatic cancer. N. Engl. J. Med. 334: 469-470.

27. Ranade K, Hussussian CJ, Sikorski RS, et al. (1995) Mutations associated with familial melanoma impair pl6INK4 function. Nature Genet. 10: 114-116.

28. Lynch HT, Fusaro RM, Pester J, et al. (1981) Tumour spectrum in the FAMMM syndrome. Br. J. Cancer 44: 553-560.

29. Greene MH, Tucker MA, Clark WH, Jr, Kraemer KH, Elder DE, Fraser MC. (1987) Hereditary melanoma and the dysplastic nevus syndrome: The risk of cancers other than melanoma. J. Am. Acad. Dermatol. 16: 792797.

30. Gutman M, Cnaan A, Inbar M, et al. (1991) Are malignant melanoma patients at higher risk for a second cancer? Cancer 68: 660665.

31. Linehan WM, Lerman MI, Zbar B. (1995) Identification of the von Hippel-Lindau (VHL) gene. Its role in renal cancer. JAMA 273: $564-570$.

32. Gayther SA, Warren W, Mazoyer S, et al. (1995) Germline mutations of the BRCAl gene in breast and ovarian cancer families provide evidence for a genotype-phenotype correlation. Nature Genet. 11: 428-433.

33. Whelan AJ, Bartsch D, Goodfellow PJ. (1995) Brief report: a familial syndrome of pancreatic cancer and melanoma with a mutation in the CDKN2 tumor-suppressor gene. N. Engl. J. Med. 333: 975-977.

34. Yarbrough WG, Aprelikova O, Pei H, Olshan AF, Liu ET. (1996) Familial tumor syndrome associated with a germline non-functional pl6(INK4a) allele. J. Natl. Cancer Inst. 88: 1489-1491.

35. Nobori T, Miura K, Wu DJ, Lois A, Takabayashi K, Carson DA. (1994) Deletions of the cyclin-dependent kinase-4 inhibitor gene in multiple human cancers. Nature 368: 753756.

36. Pollock PM, Pearson JV, Hayward NK. (1996) Compilation of somatic mutations of the CDKN2 gene in human cancers-nonrandom distribution of base substitutions. Genes Chromosome Cancer 15: 77-88.

37. Smith-Sorensen B, Hovig E. (1996) 
CDKN2A (P16(INK4A)) somatic and germline mutations. Hum. Mutat. 7: 294-303.

38. Jen J, Harper JW, Bigner SH, et al. (1994) Deletion of pl6 and pl 5 genes in brain tumors. Cancer Res. 54: 6353-6358.

39. Yoshida S, Todoroki T, Ichikawa Y, et al. (1995) Mutations of pl6Ink4/CDKN2 and p15Ink4B/MTS2 genes in biliary tract cancers. Cancer Res. 55: 2756-2760.

40. Luca M, Xie SH, Gutman M, Huang SY, Bareli M. (1995) Abnormalities in the CDKN2 (P16(INK4)/MTS-1) gene in human melanoma cells-relevance to tumor growth and metastasis. Oncogene 11: 1399-1402.

41. Nakagawa K, Conrad NK, Williams JP, Johnson BE, Kelley MJ. (1995) Mechanism of inactivation of CDKN2 and MTS2 in nonsmall cell lung cancer and association with advanced stage. Oncogene 11: 1843-1851.

42. Huang LY, Goodrow TL, Zhang SY, Kleinszanto AJP, Chang H, Ruggeri BA. (1996) Deletion and mutation analyses of the pl6/ MTS-1 tumor suppressor gene in human ductal pancreatic cancer reveals a higher frequency of abnormalities in tumor-derived cell lines than in primary ductal adenocarcinomas. Cancer Res. 56: 1137-1141.

43. Zariwala M, Liu E, Xiong Y. (1996) Mutational analysis of the pl6 family cyclin-dependent kinase inhibitors pl5(INK4B) and p18(INK4C) in tumor-derived cell lines and primary tumors. Oncogene 12: 451-455.

44. Naumann $M$, Savitskaia N, Eilert C, Schramm A, Kalthoff $\mathrm{H}$, Schmiegel W. (1996) Frequent codeletion of pl6/MTS1 and p15/MTS2 and genetic alterations in p16/MTS1 in pancreatic tumors. Gastroenterology 110: 1215-1224.

45. Miller CW, Aslo A, Campbell MJ, Kawamata N, Lampkin BC, Koeffler HP. (1996) Alterations of the p15, p16, and p18 genes in osteosarcoma. Cancer Genet. Cytogenet. 86: 136-142.

46. Wiest J, Frankin W, Otstot J, Anderson M. (1996) Identification of a novel region of homozygous deletion on chromosome $9 p$ in squamous cell carcinoma of the lung [abstract]. Proc. Am. Assoc. Cancer Res. 37: 593.

47. Brenner AJ, Aldaz CM. (1995) Chromosome $9 p$ allelic loss and p16/CDKN2 in breast cancer and evidence of p16 inactivation in immortal breast epithelial cells. Cancer Res. 55: 2892-2895.

48. Xu L, Sgroi D, Sterner CJ, et al. (1994) Mutational analysis of CDKN2 (MTS1/pl6ink4) in human breast carcinomas. Cancer Res. 54: 5262-5264.

49. Campbell IG, Foulkes WD, Beynon G, Davis M, Englefield P. (1995) LOH and mutation analysis of CDKN2 in primary human ovarian cancers. Int. J. Cancer 63: 222-225.

50. Hatta Y, Hirama T, Takeuchi S, et al. (1995) Alterations of the pl6 (MTS1) gene in testicular, ovarian, and endometrial malignancies. J Urol. 154: 1954-1957.

51. Fearon ER, Cho KR, Nigro JM, et al. (1990) Identification of a chromosome $18 \mathrm{q}$ gene that is altered in colorectal cancers. Science 247: 49-56.

52. Thiagalingam $S$, Lengauer $C$, Leach FS, et al. (1996) Evaluation of candidate tumour suppressor genes on chromosome 18 in colorectal cancers. Nature Genet. 13: 343-346.

53. Riggins GJ, Thiagalingam S, Rozenblum E, et al. (1996) Mad-related genes in the human. Nature Genet. 13: 347-349.

54. Reed JA, Loganzo F, Jr, Shea CR, et al. (1995) Loss of expression of the pl6/cyclindependent kinase inhibitor 2 tumor suppressor gene in melanocytic lesions correlates with invasive stage of tumor progression. Cancer Res. 55: 2713-2718.

55. Caldas C, Hahn SA, da Costa LT, et al. (1994) Frequent somatic mutations and homozygous deletions of the pl6 (MTS1) gene in pancreatic adenocarcinoma. Nature Genet. 8: 27-32.

56. Bartsch D, Shevlin DW, Tung WS, Kisker O, Wells SA, Goodfellow PJ. (1995) Frequent mutations of CDKN2 in primary pancreatic adenocarcinomas. Genes Chromosome Cancer 14: 189-195.

57. Bartsch D, Shevlin DW, Callery MP, Norton JA, Wells SA, Goodfellow PJ. (1996) Reduced survival in patients with ductal pancreatic adenocarcinoma associated with CDKN2 mutation. J. Natl. Cancer Inst. 88: 680-682.

58. Eiriksdottir G, Sigurdsson A, Jonasson JG, et al. (1995) Loss of heterozygosity on chromosome 9 in human breast cancer-association with clinical variables and genetic changes at other chromosome regions. Int. J. Cancer 64: 378-382.

59. Holland EA, Beaton SC, Becker TM, et al. (1995) Analysis of the pl6 gene, CDKN2, in 17 Australian melanoma kindreds. Oncogene 11: $2289-2294$.

60. Hansson J, Platz A, Linder S, Mansson BE, Lundqvist E, Inganas $P$, et al. (1996) Ger- 
mine pl6 mutations are rare in Swedish melanoma families [abstract]. Proc. Am. Assoc. Cancer Res. 37: 186.

61. Kamb A, Shattuck-Eidens D, Eeles R, et al. (1994) Analysis of the pl6 gene (CDKN2) as a candidate for the chromosome $9 \mathrm{p}$ melanoma susceptibility locus. Nature Genet. 8: 23-26.

62. Liu L, Lassam NJ, Slingerland JM, et al. (1995) Germline pl6INK4A mutation and protein dysfunction in a family with inherited melanoma. Oncogene 11: 405-412.

63. Borg A, Johansson U, Johannsson O, et al. (1996) Novel germline pl6 mutation in familial malignant melanoma in Southern Sweden. Cancer Res. 56: 2497-2500.

64. Ueki K, Rubio MP, Ramesh V, et al. (1994) MTS1/CDKN2 gene mutations are rare in primary human astrocytomas with allelic loss of chromosome 9p. Hum. Mol. Genet. 3: 1841-1845.

65. Musgrove EA, Lilischkis R, Cornish AL, et al. (1995) Expression of the cyclin-dependent kinase inhibitors pl6(INK4), p15(INK4B) and p21(WAF1/CIP1) in human breast cancer. Int. J. Cancer 63: 584-591.

66. Ohnishi $\mathrm{H}$, Kawamura $M$, Ida $K$, et al. (1995) Homozygous deletions of pl6/MTS1 gene are frequent but mutations are infrequent in childhood T-cell acute lymphoblastic leukemia. Blood 86: 1269-1275.

67. Uzawa K, Suzuki H, Yokoe H, Tanzawa H, Sato K. (1995) Mutational state of pl6/ CDKN2 and VHL genes in squamous-cell carcinoma of the oral cavity. Int. J. Oncol. 7: 895-899.

68. Calabro V, Strazzullo M, LaMantia G, Fedele M, Paulin C, Fusco A. (1996) Status and expression of the p16(INK4) gene in human thyroid-tumour cell lines. Int. J. Cancer 67: 29-34.

69. Nakamaki T, Kawamata N, Schwaller J, et al. (1995) Structural integrity of the cyclin-dependent kinase inhibitor genes, pl5, pl6 and pl8 in myeloid leukaemias. Br. J. Haematol. 91: 139-149.

70. De Vos S, Miller CW, Takeuchi S, Gombart AF, Cho SK, Koeffler HP. (1995) Alterations of CDKN2 (pl6) in non-smal cell lung cancer. Genes Chromosome Cancer 14: 164-170.

71. Yang CH, Perentesis JP. (1996) Novel mutations of the CDKN2A gene in leukemia: Potential insight into the structural basis of CDKN2A action [abstract]. Proc Am Assoc Cancer Res 37: 590.
72. Okajima E, Fukuda T, Okita S, Tsutsumi M, Hirao Y, Konishi Y. (1996) Infrequent somatic alteration of pl6/MTS1 in human primary superficial bladder cancers. Cancer Lett. 103: 227-231.

73. Platz A, Ringborg U, Lagerlof B, Lundqvist E, Sevigny P, Inganas M. (1996) Mutational analysis of the CDKN2 gene in metastases from patients with cutaneous malignant melanoma. Br. J. Cancer 73: 344-348.

74. Rasool O, Heyman M, Brandter LB, et al. (1995) pl5ink4B and pl6ink4 gene inactivation in acute lymphocytic leukemia. Blood 85: 3431-3436.

75. Uchida $T$, Watanabe $T$, Kinoshita $T$, Murate T, Saito H, Hotta T. (1995) Mutational analysis of the CDKN2 (MTS1/p16ink4A) gene in primary B-cell lymphomas. Blood 86: 2724-2731.

76. Esteve A, Martelplanche G, Sylla BS, Hollstein M, Hainaut P, Montesano R. (1996) Low frequency of p16/CDKN2 gene mutations in esophageal carcinomas. Int. J. Cancer 66: 301-304.

77. Ueki K, Ono Y, Hensen JW, Efird JT, von Deimling A, Louis DN. (1996) CDKN2/p16 or $\mathrm{Rb}$ alterations occur in the majority of glioblastomas and are inversely correlated. Cancer Res. 56: 150-153.

78. Shimizu T, Sekiya T. (1995) Loss of heterozygosity at 9p2 1 loci and mutations of the MTS1 and MTS2 genes in human lung cancer. Int. J. Cancer 63: 616-620.

79. Konishi N, Hiasa Y, Tsuzuki T, et al. (1996) Detection of $\mathrm{Rb}, \mathrm{p} 16 / \mathrm{CDKN} 2$ and P15 (INK4B) gene alterations with immunohistochemical studies in human prostate carcinomas. Int. J. Oncol. 8: 107-112.

80. Maelandsmo GM, Florenes VA, Hovig E, et al. (1996) Involvement of the $\mathrm{pRb} / \mathrm{pl6} /$ CDK4/cyclin D 1 pathway in the tumorigenesis of sporadic malignant melanomas. $B r . J$. Cancer 73: 909-916.

81. Ohta M, Berd D, Shimizu M, et al. (1996) Deletion mapping of chromosome region 9p21-p22 surrounding the CDKN2 locus in melanoma. Int. J. Cancer 65: 762-767.

82. Rusin MR, Okamoto A, Chorazy M, et al. (1996) Intragenic mutations of the pl6(INK4), pl5(INK4B) and pl8 genes in primary non-small-cell lung cancers. Int. $J$. Cancer 65: 734-739.

83. Haider MA, Cao XB, Manshouri T, Chan LL, Glassman A, Kantarjian HM.

(1995) 
p16(INK4A) and p15(INK4B) gene deletions in primary leukemias. Blood 86: 311-315.

84. Kyritsis AP, Zhang BH, Zhang W, et al. (1996) Mutations of the pl6 gene in gliomas. Oncogene 12: 63-67.

85. Berns EMJJ, Klijn JGM, Smid M, Vanstaveren IL, Gruis NA, Foekens JA. (1995) Infrequent CDKN2 (MTS1/pl6) gene alterations in human primary breast cancer. Br. J. Cancer 72: 964-967.

86. Nakao M, Yokota S, Kaneko H, et al. (1996) Alterations of CDKN2 gene structure in childhood acute lymphoblastic leukemiamutations of CDKN2 are observed preferentially in T lineage. Leukemia 10: 249-254.

87. Tung WS, Shevlin DW, Bartsch D, Norton JA, Wells SA, Goodfellow PJ. (1996) Infrequent CDKN2 mutation in human differentiated thyroid cancers. Mol. Carcinog. 15: 5-10.

88. Qin LX, Tang ZY, Liu KD, et al. (1996) Alterations of CDKN2(pl6/MTS1) exon 2 in human hepatocellular carcinoma. Oncol. Rep. 3: 405-408.

89. Miyamoto H, Kubota Y, Fujinami K, et al. (1995) Infrequent somatic mutations of the pl6 and pl 5 genes in human bladder cancer-p16 mutations occur only in low-grade and superficial bladder cancers. Oncol. Res. 7: 327-330.

90. Cayuela JM, Madani A, Sanhes L, Stern MH, Sigaux F. (1996) Multiple tumor-suppressor gene 1 inactivation is the most frequent genetic alteration in T-cell acute lymphoblastic leukemia. Blood 87: 2180-2186.

91. Gonzalez-Zulueta $M$, Shibata A, Ohneseit PF, et al. (1995) High frequency of chromosome 9p allelic loss and CDKN2 tumor suppressor gene alterations in squamous cell carcinoma of the bladder. J. Natl. Cancer. Inst. 87: 1383-1393.

92. Sonoda Y, Yoshimoto T, Sekiya T. (1995) Homozygous deletion of the MTS $1 / \mathrm{pl} 6$ and MTS2/p15 genes and amplification of the CDK4 gene in glioma. Oncogene 11: 21452149.

93. Igaki H, Sasaki H, Tachimori $Y$, et al. (1995) Mutation frequency of the p16/CDKN2 gene in primary cancers in the upper digestive tract. Cancer Res. 55: 3421-3423.

Accepted on August 16, 1996. 